\title{
Evaluation of Prunus domestica gum as a novel tablet binder
}

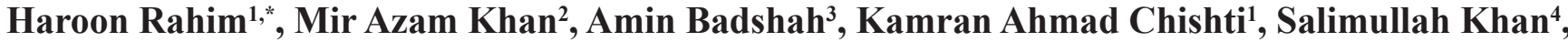 \\ Muhammad Junaid ${ }^{2}$
}

\author{
${ }^{1}$ Department of Pharmacy, Sarhad University of Science and Information Technology Peshawar, Khyber Pakhtunkhwa, \\ Pakistan, ${ }^{2}$ Department of Pharmacy, University of Malakand, Chakdara Dir Lower, Khyber Pakhtunkhwa, Pakistan, \\ ${ }^{3}$ Department of Chemistry, Quaid-e-Azam University, Islamabad, Pakistan, ${ }^{4}$ Department of Pharmacy, University of Swabi, \\ Khyber Pakhtunkhwa, Pakistan
}

\begin{abstract}
To evaluate binding potential of Prunus domestica gum in tablets formulations. Six tablet batches (F$1 \mathrm{~B}$ to F-6B) were prepared by wet granulation method, containing Avicel $\mathrm{pH} 101$ as diluent, sodium diclofenac as model drug using 10,15 and $20 \mathrm{mg}$ of Prunus domestica gum as binder and PVP K30 was used as standard binder. Magnesium stearate was used as lubricant. Flow properties of granules like bulk density, tapped density, Carr index, Hausner's ratio, angle of repose as well as physical parameters of the compressed tablets including hardness, friability, thickness and disintegration time were determined and found to be satisfactory. The FTIR spectroscopic analysis showed that the formulation containing plant gum is compatible with the drug and other excipients used in tablets formulation. Hence the plant gum has role as a potential binder in tablets formulations. The dissolution profile showed that tablets formulations containing Prunus domestica gum $15 \mathrm{mg} / 200 \mathrm{mg}$ of total weight of tablet as binder showed better results as compared to PVP K30.
\end{abstract}

Uniterms: Prunus domestica/pharmaceutics. Plant gum/binder property. Plant binder. Tablets/ formulations. Sodium diclofenac/tablets/analysis.

\begin{abstract}
Para avaliar a propriedade aglutinante da goma Prunus domestica em formulações de comprimidos, seis lotes (F-1B para F-6B) foram preparados pelo método de granulação úmida, contendo Avicel pH 101 como diluente e diclofenaco de sódio como fármaco modelo, usando 10, 15 e $20 \mathrm{mg}$ de goma de Prunus domestica como agente aglutinante e PVP K30 como aglutinante padrão. O estearato de magnésio foi utilizado como lubrificante. Propriedades de fluxo dos grânulos, como a densidade, índice de Carr, razão de Hausner, ângulo de repouso, bem como parâmetros físicos dos comprimidos, incluindo o tempo de dureza, friabilidade, espessura e desintegração foram determinados e se mostraram satisfatórios. A análise espectroscópica no FTIR mostrou que a formulação contendo goma vegetal é compatível com o fármaco e outros excipientes utilizados na formulação dos comprimidos. Assim, a goma vegetal tem papel potencial como aglutinante em formulações de comprimidos. O perfil de dissolução das formulações que contêm $15 \mathrm{mg} / 200 \mathrm{mg}$ do peso total do comprimido em goma de Prunus domestica como aglutinante mostrou melhores resultados comparativamente ao PVP K30.
\end{abstract}

Unitermos: Prunus domestica/farmacotécnica. Goma vegetal/propriedade aglutinante. Aglutinante vegetal. Comprimidos/formulações. Diclofenaco de sódio/comprimidos/análise.

\section{INTRODUCTION}

Gum is a by-product obtained as an outcome of metabolic mechanism of plants. Gums obtained from natural sources either absorb water to form a viscous solution or water soluble. These gums are easily

\footnotetext{
*Correspondence: Haroon Rahim. Department of Pharmacy, Sarhad University of Science and Information Technology Peshawar, Khyber Pakhtunkhwa, Pakistan. E-mail: hrahimpk@gmail.com
}

available, less expensive and also employed as excipient in pharmaceutical formulations (Sarojini et al., 2010). Plant derived natural polysaccharides are more suitable pharmaceutical excipient due to non-toxicity, stability, availability, renewability and are, therefore, extensively used as matrix formers in modified release dosage forms (Beneke, Viljoen, Hamman, 2009; Nep, Conway, 2010). Natural gums obtained from plants have various applications in drug delivery as disintegrant, emulsifying agent, suspending agents, binders and are also useful in 
formulating immediate and sustained release preparations (Ibrahim, Dawes, Bangudu, 2000; Sinha, Kumaria, 2002; Oluwatoyin, 2005; Emeje et al., 2009).

Prunus domestica belongs to family Rosaceae, are small to medium size trees, found throughout Pakistan including Azad Jammu and Kashmir region (Gilani et al., 2011). Prunus domestica fruits are used locally to treat jaundice and hepatitis and its gum is used as a tonic, laxative, and vermifuge (Abbasi et al., 2009; Lardos, Prietos-Garcia, Heinrich, 2011). Diclofenac sodium is a non-steroidal anti-inflammatory drug (NSAID), which is poorly soluble in water and freely soluble in organic solvent like methanol. It is commonly used as analgesic, antipyretic, anti-inflammatory and for the long-term treatment of rheumatoid arthritis (Ganish et al., 2010). Plant gums have been used as binders in tablet formulations. They are useful for imparting the structural strength required during the processing, handling and packaging of tablets as well as these plant gums are of non-toxic nature and widely available.

No work has been done on Prunus domestica gum as tablet binder. Hence the gum is widely available and need to be evaluated by using as an excipient in tablet formulations.

\section{MATERIAL AND METHODS}

\section{Material}

Diclofenac sodium, Avicel pH 101, Aerosil, magnesium stearate and PVP K30 were provided by Prays Pharmaceuticals (Pvt) Ltd, Islamabad, Pakistan. Hydrochloric acid, methanol, sodium hydroxide and potassium dihydrogen phosphate were purchased from Musaji and Sons, Khyber Bazaar, Peshawar, Pakistan. All other chemicals used were of analytical grade.

\section{Collection of Prunus domestica gums}

Gums were collected from the plants of $P$. domestica, (Family Rosaceae) in April, 2010 from Sheringal valley of District Dir Upper, Khyber Pakhtunkhwa, Pakistan. Gums were natural exudates on the bark of the plant. The plant was identified by Prof. Dr. Jehandar Shah, Vice Chancellor, Shaheed Benazir Bhutto University, Sheringal (Dir Upper) Khyber Pakhtunkhwa, Pakistan. The specimen sample (PG-02-10) was kept in Department of Pharmacy, University of Malakand, Chakdara, Dir Lower, Khyber Pakhtunkhwa, Pakistan. After collection, gums were dried in oven at $60{ }^{\circ} \mathrm{C}$. Gums were then hydrated to remove extraneous materials by straining through a muslin cloth.
The gums were then precipitated from the solution using absolute acetone. The precipitate was separated, dried in oven at $50{ }^{\circ} \mathrm{C}$ and stored in tightly closed container for future use as binder in formulating matrix tablets.

\section{Preparation and evaluation of granules}

Granules of various formulations containing $50 \mathrm{mg}$ of sodium diclofenac were prepared by wet granulation method. Natural gum (Prunus domestica) in different ratios was used as binder and PVP K30 as a standard binder. Diclofenac sodium, Avicel pH 101, Aerosil and gum were separately mixed, thoroughly, and sufficient quantity of water was added as granulating agent. The damp mass was passed through mesh 12. Granules obtained were allowed to dry at $60{ }^{\circ} \mathrm{C}$ for $4-5$ hours and were then passed through mesh 18 . Finally magnesium stearate was added as lubricant to each batch prior to compression of granules. The quantities of ingredients of all the formulation batches are given in Table I.

\section{Evaluation of granules}

The bulk density, tapped density, Hausner's ratio, compressibility index and angle of repose were determined for each batch of dried granules.

\section{Bulk density}

Granules of known weight $(\mathrm{m})$ were poured in $10 \mathrm{~mL}$ graduated cylinder, unsettled volume $\left(\mathrm{V}_{0}\right)$ was noted and bulk density was calculated $(\mathrm{g} / \mathrm{mL})$ by formula $\mathrm{m} / \mathrm{V}_{0}$ (Lachman, Lieberman, Kanig 2003).

\section{Tapped density}

The graduated cylinder $(10 \mathrm{~mL})$ containing known weight $(\mathrm{m})$ of granules was tapped on a hard surface until no further change in volume was observed. The tapped volume $\left(\mathrm{V}_{\mathrm{T}}\right)$ was noted and tapped density was calculated by putting values in formula, $\mathrm{m} / \mathrm{V}_{\mathrm{T}}$ (Bamiro et al., 2010).

\section{Compressibility index}

It was determined by Carr's compressibility index i.e. by formula given:

$$
\text { Compressibility index }=\left(\mathrm{T}_{\mathrm{d}}-\mathrm{B}_{\mathrm{d}} / \mathrm{T}_{\mathrm{d}}\right) \times 100
$$

where $\mathrm{Td}$ is tapped density and $\mathrm{Bd}$ is bulk density.

\section{Hausner's ratio}

It was calculated by the following formula (Shivanand, 2010): 
TABLE I - Formulation of different batches of sodium diclofenac tablets

\begin{tabular}{lcccccc}
\hline Ingredients (mg) & F-1B & F-2B & F-3B & F-4B & F-5B & F-6B \\
\hline Diclofenac sodium & 50 & 50 & 50 & 50 & 50 & 50 \\
Prunus domestica gum & 10 & 15 & 20 & --- & --- & --- \\
Avicel pH 101 & 133 & 128 & 123 & 133 & 128 & 123 \\
PVP K30 (binder) & ---- & --- & --- & 10 & 15 & 20 \\
Aerosil & 4 & 4 & 4 & 4 & 4 & 4 \\
Distilled water & q.s & q.s & q.s & q.s & q.s & q.s \\
Magnesium stearate & 3 & 3 & 3 & 3 & 3 & 3 \\
\hline Total weight (mg) & 200 & 200 & 200 & 200 & 200 & 200 \\
\hline
\end{tabular}

Key: --- means absent

$$
\text { Hausner's ratio }=\mathrm{Td} / \mathrm{B}_{\mathrm{d}}
$$

where Td is tapped and Bd is bulk density.

\section{Angle of repose}

It was determined by filling $10 \mathrm{~g}$ of powder in a funnel. Then, the funnel was opened to release the powder on the paper to form a conical heap. The values were calculated by formula (Shivanand., 2010),

$$
\tan \theta=\mathrm{h} / \mathrm{r} \text { or } \theta=\tan ^{-1} \mathrm{~h} / \mathrm{r}
$$

where $\mathrm{h}=$ height of the heap; $\mathrm{r}=$ radius of the heap

\section{Preparation of sodium diclofenac tablets}

Tablets were prepared by compressing granules on rotary compression machine using concave punch $(8 \mathrm{~mm})$. Total weight of tablet was kept as $200 \mathrm{mg}$ (ZP19 Rotary Tablet Press, Shanghai, China).

\section{Evaluation of tablets}

Average weight

Twenty tablets were weighed by analytical balance (Sartorius BL 2105, Germany) after compression, then average weight and standard deviation was determined (United States Pharmacopoeia, 2004).

\section{Drug Content}

Tablets (10) were accurately weighed and powdered. Powder amount equivalent to $50 \mathrm{mg}$ Diclofenac sodium was shaken with $60 \mathrm{~mL}$ of methanol in a $200 \mathrm{~mL}$ volumetric flask and final volume was make up with methanol, $5 \mathrm{~mL}$ of this solution was further diluted to $100 \mathrm{~mL}$ with methanol and absorbance was measured using spectrophotometer (UV-1601 Shimadzu, Japan) at
$276 \mathrm{~nm}$. The content was determined by preparing same concentration of sodium diclofenac in the same solvent and absorbance was measured at $276 \mathrm{~nm}$. The \% content was determined by (Shingala et al., 2010):

$\%$ Drug content $=\frac{\text { Absorbance of sample } \times \text { average weight oftablet }}{\text { Absorbance of standard } \times \text { weight of sampl }} \times 100$

\section{Hardness}

Hardness of 10 tablets was determined by using digital hardness tester (Pharma Test) and mean \pm S.D. of each formulation mentioned in Table III (Shingala et al., 2010).

\section{Thickness}

The thickness of 10 tablets was determined using vernier calipers and average values were calculated (Shingala et al., 2010).

\section{Friability}

The friability of tablets (10) was determined using Roche Friabilator. Ten tablets were initially weighed $\left(\mathrm{W}_{0}\right)$ and transferred into friabilator. The friabilator was operated at $25 \mathrm{rpm}$ for 4 minutes or was run up to 100 revolutions. The tablets were weighed again (W). The \% friability was then calculated (Shivanand., 2010):

$$
\% \text { Friability }=(\mathrm{W} 0-\mathrm{W}) / \mathrm{W} 0 \times 100
$$

where $\mathrm{W} 0=$ initial weight of 10 tablets; $\mathrm{W}=$ weight of 10 tablets after 100 revolutions; \% Friability of tablets less than $1 \%$ were considered acceptable.

\section{Disintegration time}

The method specified in the USP/NF (2007) was followed for Disintegration time, medium used was $100 \mathrm{~mL}$ of $0.1 \mathrm{~N} \mathrm{HCl}$ maintained at temperature between $37 \pm 2{ }^{\circ} \mathrm{C}$ 
throughout the experiment. Five tablets were randomLy selected from each batch and were placed one in each of the cylindrical tubes of the basket using disintegration test apparatus (DT-0607, Curio) but no disc was used. The time taken for each tablet to break up into small particles and pass out through the mesh was noted (Satyam., 2010).

\section{In-Vitro dissolution studies}

In-vitro dissolution test of the all the batches compressed Diclofenac sodium tablet was performed using USP dissolution apparatus 2 (Pharma Test DT-70, Germany), using phosphate buffer $\mathrm{pH} 6.8$ as dissolution medium. The temperature was maintained at $37 \pm 2{ }^{\circ} \mathrm{C}$ using rotation speed $50 \mathrm{rpm}$. Samples were withdrawn at regular intervals (10 minutes) up to 1 hour, replacing equal amount of fresh dissolution medium (phosphate buffer $\mathrm{pH}$ 6.8). Samples were analyzed using UV spectrophotometer at $276 \mathrm{~nm}$ and \% cumulative drug release was calculated (Satyam., 2010).

\section{Release kinetics}

Different kinetic models (zero-order, first-order, Higuchi's, and Korsmeyer's equation) were applied to interpret the release profile (the order and mechanism of sodium diclofenac release) from tablet. To study the mechanism of drug release from the tablets, the release data were fitted to zero-order, first-order, and Higuchi equation. However, two factors diminish the applicability of Higuchi's equation to matrix systems. This model fails to allow the influence of swelling of the matrix (upon hydration) and gradual erosion of the matrix. Therefore, the dissolution data were also fitted according to the well-known exponential equation (Korsmeyer equation), Eq. (1), which is often used to describe the drug release behavior from polymeric systems.

$$
\log (\mathrm{Mt} / \mathrm{Mf})=\log \mathrm{k}+\mathrm{n} \log \mathrm{t}
$$

where, Mt is the amount of drug release at time t; $\mathrm{Mf}$ is the amount of drug release after infinite time; $k$ is a release rate constant incorporating structural and geometric characteristics of the tablet; and $\mathrm{n}$ is the diffusional exponent indicative of the mechanism of drug release. To clarify the release exponent for different batches of matrix tablets, the log value of percentage drug dissolved was plotted against log time for each batch according to the equation 1 . A value of $\mathrm{n}=0.45$ indicates Fickian (case I) release; $>0.45$ but $<0.89$ for non-Fickian (anomalous) release; and $>0.89$ indicates super case II type of release.
Case II generally refers to the erosion of the polymeric chain and anomalous transport (non-Fickian) refers to a combination of both diffusion and erosion controlled-drug release (Siva PG, Mohini K, 2012).

\section{FTIR Studies}

To study any possible interaction between drug and the plant gum FTIR spectroscopic analysis were carried out. The drug, plant gum and optimized formulation blend i.e. batch F-3B (blend contain Prunus domestica gum, sodium diclofenac, Avicel and magnesium stearate) compatibility were studied by using IR spectrophotometer (Nicolet FTIR spectrophotometer, Thermoscientific Nicolet, USA). A small amount of sodium diclofenac, plant gum and formulation blend were respectively placed directly on the germanium piece of the infrared spectrometer with constant pressure applied and data of infrared absorbance, collected over the wave number ranged from $4000 \mathrm{~cm}^{-1}$ to $400 \mathrm{~cm}^{-1}$ and was expressed in $\mathrm{cm}^{-1}$ (Nazneen, Wesely, Johnson, 2012).

\section{RESULTS AND DISCUSSION}

The current study was undertaken to evaluate the binding potential of Prunus domestica gum using sodium diclofenac was used as model drug in formulation of tablets. The granules of different formulation batches prepared (as shown in Table I) were evaluated different parameters like angle of repose $(\theta)$, bulk and tapped densities, compressibility index, Hausner's ratio and the results are (shown in Table II) angle of repose of all the formulated batches ranges from 29.34 to 35.86, indicating good flow properties (Reza, Mohammad, Yousef, 2012).

Physical characterization of all the batches (shown in Table III) showing acceptable values of thickness, weight variation (ranged from $199.25 \pm 3.89$ to $201.50 \pm 3.17$ ) was found within limit i.e. \pm 7.5 for the $200 \mathrm{mg}$ tablet as per USP, hardness (ranged from $7.50 \pm 0.63$ to $7.95 \pm 0.68 \mathrm{~kg} / \mathrm{cm}^{2}$ ), friability (ranged from 0.14 to $0.67 \%$ ) within the acceptance range i.e. less than $1 \%$, disintegration time ( $\leq 15$ minutes) was found to be acceptable as all the batches and drug content (ranged from $98.02 \pm 0.75$ to $100.42 \pm 0.96 \%$ ) was that claimed.

\section{In-Vitro Dissolution Studies}

In-vitro dissolution in phosphate buffer $\mathrm{pH} 6.8$, batch F-2B (containing 7.5\% Prunus domestica gum per total weight of tablet) release showed $98.67 \%$ of drug releases at the end of $50 \mathrm{~min}$, which is compared with 
TABLE II - Evaluation of granules

\begin{tabular}{lcccccc}
\hline Properties & F-1B & F-2B & F-3B & F-4B & F-5B & F-6B \\
\hline Bulk density $(\mathrm{g} / \mathrm{ml})$ & $0.577 \pm 0.00$ & $0.592 \pm 0.01$ & $0.601 \pm 0.00$ & $0.488 \pm 0.00$ & $0.491 \pm 0.00$ & $0.494 \pm 0.00$ \\
Tapped density $(\mathrm{g} / \mathrm{ml})$ & $0.636 \pm 0.01$ & $0.662 \pm 0.01$ & $0.660 \pm 0.01$ & $0.582 \pm 0.00$ & $0.580 \pm 0.00$ & $0.590 \pm 0.01$ \\
Carr's index & $0.927 \pm 0.59$ & $10.61 \pm 0.54$ & $8.91 \pm 0.94$ & $15.88 \pm 0.72$ & $15.33 \pm 0.84$ & $16.19 \pm 0.56$ \\
Hausner's ratio & $1.09 \pm 0.01$ & $1.11 \pm 0.00$ & $1.09 \pm 0.01$ & $1.18 \pm 0.00$ & $1.17 \pm 0.01$ & $1.18 \pm 0.00$ \\
Angle of repose $\left(^{\circ}\right)$ & 32.04 & 31.41 & 29.34 & 35.86 & 34.07 & 33.49 \\
\hline
\end{tabular}

All the values are expressed as mean $\pm \mathrm{SD}$

TABLE III - Evaluation of sodium dicloefenac tablets

\begin{tabular}{lcccccc}
\hline $\begin{array}{l}\text { Tablet } \\
\text { Batches }\end{array}$ & $\begin{array}{c}\text { Hardness } \\
\left(\mathbf{K g} / \mathbf{c m}^{\mathbf{2}}\right)\end{array}$ & $\begin{array}{c}\text { Weight variation } \\
\mathbf{( \% )}\end{array}$ & $\begin{array}{c}\text { Thickness } \\
\mathbf{( m m})\end{array}$ & $\begin{array}{c}\text { Friability* } \\
\mathbf{( \% )}\end{array}$ & $\begin{array}{c}\text { Disintegration } \\
\text { time* }^{(\mathbf{m i n})}\end{array}$ & $\begin{array}{c}\text { Drug content } \\
\mathbf{( \% )}\end{array}$ \\
\hline F-1B & $7.50 \pm 0.63$ & $200.80 \pm 3.24$ & $4.32 \pm 1.04$ & 0.67 & 3.40 & $98.02 \pm 0.75$ \\
F-2B & $7.83 \pm 0.58$ & $200.30 \pm 3.15$ & $4.32 \pm 1.08$ & 0.54 & 8.20 & $98.99 \pm 0.65$ \\
F-3B & $7.95 \pm 0.68$ & $200.80 \pm 3.22$ & $4.31 \pm 1.12$ & 0.42 & 13.30 & $100.34 \pm 1.09$ \\
F-4B & $7.94 \pm 0.63$ & $199.25 \pm 3.89$ & $4.36 \pm 1.13$ & 0.38 & 4.40 & $98.62 \pm 0.72$ \\
F-5B & $7.77 \pm 0.51$ & $201.50 \pm 3.17$ & $4.34 \pm 1.03$ & 0.24 & 9.10 & $100.42 \pm 0.96$ \\
F-6B & $7.65 \pm 0.65$ & $200.48 \pm 3.56$ & $4.30 \pm 0.91$ & 0.14 & 15.00 & $99.36 \pm 1.04$ \\
\hline
\end{tabular}

All the values are expressed as mean \pm SD except data denoted by asterisk $(*)$

F-5B (containing standard binder PVP K30 at 7.5\% of total weight of tablet) formulation showed $89.03 \%$ drug release at the end of $30 \mathrm{~min}$. Batch F-3B (containing 10\% of Prunus domestica gum) showed $74.86 \%$ drug release at the end of 60 min. Batch F-6B released $98.8 \%$ drug at the end of $60 \mathrm{~min}$. Hence, it can be concluded that the binding potential of Prunus domestica better as compared to PVP K30. These results are shown in Figure 1.

\section{Release Kinetics}

All the batches obey zero order kinetics with values of $\mathrm{r}^{2}$ 0.8753, 0.9907, 0.9420, 0.5640, 0.8087 and 0.9809 for F-1B, F-2B, F-3B, F-4B, F-5B and F-6B respectively. Formulation batches F-3B, F-4B and F-5B follow Fickian

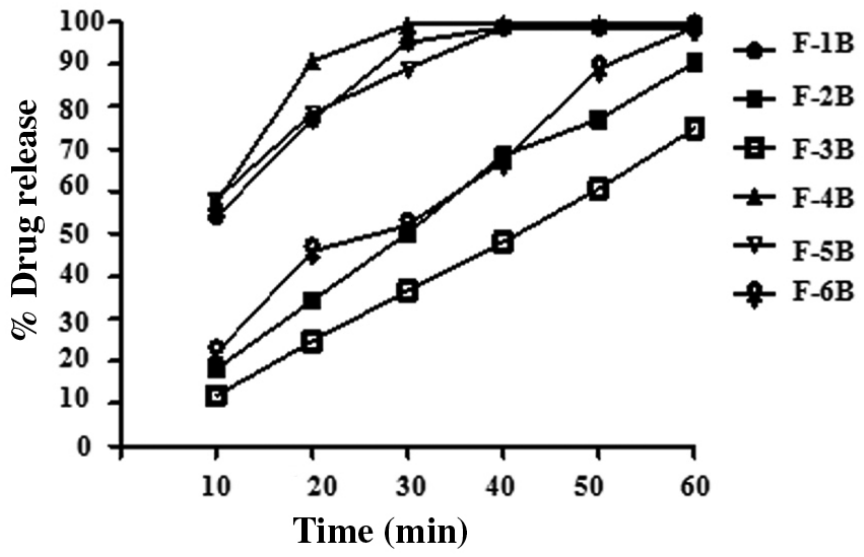

FIGURE 1 - In Vitro drug release profile of sodium diclofenac tablets.

TABLE IV - In-vitro release kinetics of diclofenac sodium tablets

\begin{tabular}{lccccccc}
\hline Formulation & Zero Order & First Order & Higuchi & $\begin{array}{c}\text { Hixson } \\
\text { Crowell }\end{array}$ & \multicolumn{2}{c}{ Korsmeyer } & $\begin{array}{c}\text { Release } \\
\text { mechanism }\end{array}$ \\
\cline { 2 - 5 } & $\mathbf{r}^{\mathbf{2}}$ & $\mathbf{r}^{\mathbf{2}}$ & $\mathbf{r}^{\mathbf{2}}$ & $\mathbf{r}^{\mathbf{2}}$ & $\mathbf{r}^{\mathbf{2}}$ & $\mathbf{N}$ & \\
\hline F-1B & 0.8753 & 0.8001 & 0.9389 & 0.9512 & 0.9870 & 0.718 & non-Fickian \\
F-2B & 0.9907 & 0.9183 & 0.9320 & 0.9810 & 0.9722 & 0.781 & non-Fickian \\
F-3B & 0.9420 & 0.8879 & 0.7041 & 0.9172 & 0.7071 & 0.428 & Fickian \\
F-4B & 0.5640 & 0.5395 & 0.5619 & 0.6827 & 0.6873 & 0.240 & Fickian \\
F-5B & 0.8087 & 0.7706 & 0.7851 & 0.8847 & 0.8729 & 0.258 & Fickian \\
F-6B & 0.9809 & 0.9127 & 0.9871 & 0.9106 & 0.9742 & 0.712 & non-Fickian \\
\hline
\end{tabular}


TABLE V - In vitro release kinetics of sodium diclofenac tablets

\begin{tabular}{lccc}
\hline Bonds/Group & Absorption range in $\mathbf{c m}^{-1}$ & Pure Drug & Formulation F-3B \\
\hline - NH & $3500-3200$ & 3251.3 & 3221.0 \\
C-H & $3100-2850$ & 3084.0 & 2917.9 \\
C=C & $1900-1500$ & 1573.5 & 1572.7 \\
C-Cl & $1280-1350$ & 1281.5 & 1306.2 \\
C-N & $1300-800$ & 1044.1 & 1035.6 \\
C-C & $850-550$ & 844.4 & 838.5 \\
\hline
\end{tabular}

Drug excipients compatibility studies

TABLE VI - For FTIR data interpretation

\begin{tabular}{|c|c|c|c|c|c|c|c|}
\hline \multirow{2}{*}{ Formulation } & \multirow{2}{*}{$\begin{array}{c}\text { Zero Order } \\
\mathbf{r}^{2} \\
\end{array}$} & \multirow{2}{*}{$\frac{\text { First Order }}{\mathbf{r}^{2}}$} & \multirow{2}{*}{$\begin{array}{c}\text { Higuchi } \\
r^{2}\end{array}$} & \multirow{2}{*}{$\begin{array}{c}\text { Hixson } \\
\text { Crowell }\end{array}$} & \multicolumn{2}{|c|}{ Korsmeyer } & \multirow{2}{*}{$\begin{array}{c}\text { Release } \\
\text { mechanism }\end{array}$} \\
\hline & & & & & $\mathbf{r}^{2}$ & $\mathbf{N}$ & \\
\hline$\overline{F-1 B}$ & 0.8753 & 0.8001 & 0.9389 & 0.9512 & 0.9870 & 0.718 & non-Fickian \\
\hline F-2B & 0.9907 & 0.9183 & 0.9320 & 0.9810 & 0.9722 & 0.781 & non-Fickian \\
\hline F-3B & 0.9420 & 0.8879 & 0.7041 & 0.9172 & 0.7071 & 0.428 & Fickian \\
\hline F-4B & 0.5640 & 0.5395 & 0.5619 & 0.6827 & 0.6873 & 0.240 & Fickian \\
\hline F-5B & 0.8087 & 0.7706 & 0.7851 & 0.8847 & 0.8729 & 0.258 & Fickian \\
\hline F-6B & 0.9809 & 0.9127 & 0.9871 & 0.9106 & 0.9742 & 0.712 & non-Fickian \\
\hline
\end{tabular}

(Case I) release, while the rest of batches obey NonFickian type release pattern which mean that combination of erosion and diffusion controlled drug release is shown by the formulations, as evident from the Table $\mathrm{V}$. A value of $\mathrm{n}=0.45$ indicates Fickian (case I) release; $>0.45$ but $<0.89$ for non-Fickian (anomalous) release; and $>0.89$ indicates super case II type of release. Case II generally refers to the erosion of the polymeric chain and anomalous transport (non-Fickian) refers to a combination of both diffusion and erosion controlled-drug release.

\section{Drug excipients compatibility studies}

Drug excipients compatibilities studies were carried out by using IR spectroscopy. IR Spectra of Drug (sodium diclofenac) and optimized formulation F-3B (Drug, excipients and plant gum mixture) were analyzed. The IR spectra of pure diclofenac sodium and its physical mixtures with other excipients are shown in figures $(2,3$ and 4) and interpretations were listed in Table VI.

The distinct peaks of pure drug were at 3251.5, $3084.0,1573.5,1281.5,844.4 \mathrm{~cm}^{-1}$, while the batch containing Prunus domestica gum as binder showed peaks at 3221.0, 2917.9, 1572.7, 1306.2, 1035.6 and $838.5 \mathrm{~cm}^{-1}$. The distinct peaks are appeared in both pure

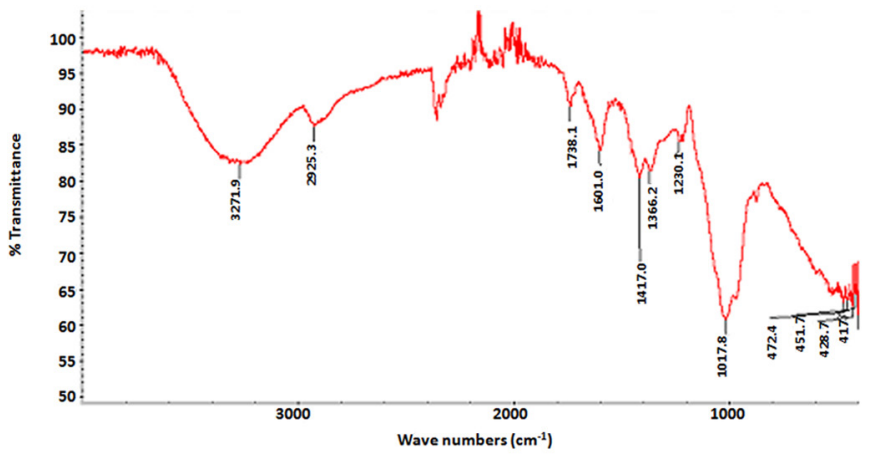

FIGURE 2 - FTIR spectrum Prunus domestica gum.

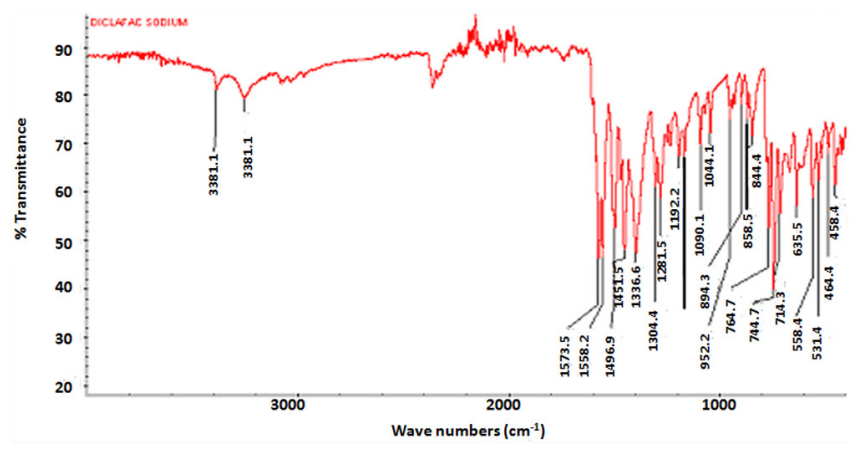

FIGURE 3 - FTIR spectrum sodium diclofenac. 


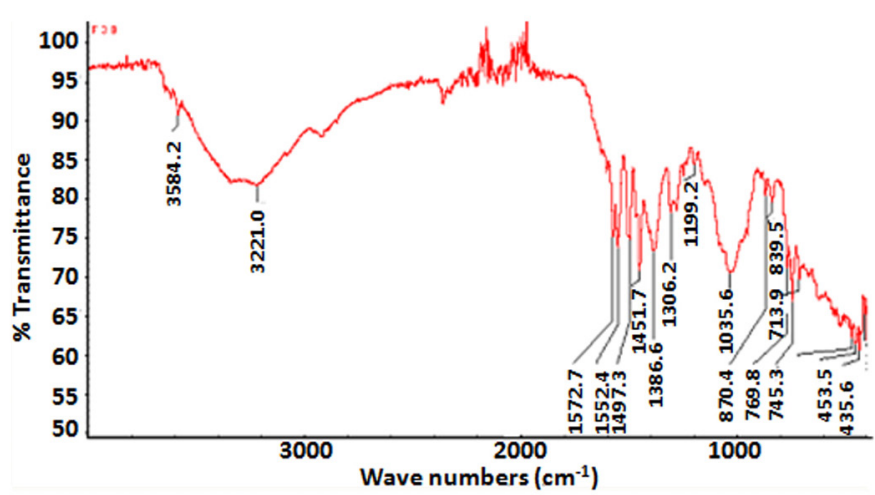

FIGURE 4 - FTIR spectrum of formulation blend containing Prunus domestica gum.

drug (diclofenac sodium) and formulation containing Prunus domestica gum, indicating no chemical interaction between diclofenac sodium and Prunus domestica gum as confirmed by FTIR. Hence, the gum is safe to use as an excipient in formulation of Diclofenac sodium tablets.

\section{CONCLUSION}

Batch F-2B release showed $50.23 \%$ of drug releases at the end of 30 min, which is compared with F-5B formulation, showed $89.03 \%$ drug release at the end of 30 min. Batch F-3B showed $74.86 \%$ drug release at the end of 60 min while batch F-6B released $98.8 \%$ drug at the end of $60 \mathrm{~min}$. Hence, it is concluded that Prunus domestica has better binding potential as compared to PVP K30. Hence, Prunus domestica gum, a natural excipient, can be used as a binder in tablet formulations.

\section{REFERENCES}

ABBASI, A.M.; KHAN, M.A.; AHMAD, M.; ZAFAR, M.; KHAN, H.; MUHAMMAD, N.; SULTANA, S. Medicinal plants used for the treatment of jaundice and hepatitis based on socio- economic documentation. Afr. J. Biotechnol., v.8, p.1643-1650, 2009.

BAMIRO, O.A.; SINHA, V.R.; KUMAR, R.; ODEKU, O.A. Characterization and evaluation of Terminalia randii gum as a binder in carvedilol tablet formulation. Acta Pharm. Sci., v.52, p.254-262, 2010.

BENEKE, E.C.; VILJOEN, A.M.; HAMMAN, J.H. Plantderived excipients in drug delivery. Molecules, v.14, p.2602-2620, 2009.
EMEJE, M.; NWABUNIKE, P.; ISIMI, C.; FORTUNAK, J.; MITCHELL, J.W.; BYRN, S.; KUNLE, O.; OFOEFULE, $\mathrm{S}$. Isolation, characterization and formulation properties of a new plant gum obtained from Cissus refescence. Afr. J. Pharm. Pharmacol., v.3, p.16-23, 2009.

GANESH, G.N.K.; KUMAR, R.S.; JAWAHAR, N.; SENTHIL, V.; VENKATESH, D.N.; SRINIVAS, M.S. Preparation and evaluation of sustained release matrix tablet of diclofenac sodium using natural polymer. JPSR, v.2, p.360-368, 2010. Abbreviation

GILANI, S.A.; QURESHI, R.A.; KHAN, A.M.; ULLAH, F.; NAWAZ, Z.; AHMAD. I.; POTTER, D. A molecular phylogeny of selected species of Genus Prunus L. (Rosaceae) from Pakistan using the TRN-L \& TRN-F spacer DNA. Afr. J. Biotechnol., v.10, p.4550-4554, 2011.

IBRAHIM, M.A.; DAWES, V.H.; BANGUDU, A.B. Evaluation of cissus populnea polymer as a matrix former for controlled drug release. J. Phytomed. Therap., v.5, p.23-32, 2000.

LACHMAN, L.; LIEBERMAN, H.A.; KANIG, J.L. The theory and practice of industrial pharmacy: evaluation of tablets. 3.ed. Bombay: Varghese Publishing House, 2003. p.296-303.

LARDOS, A.; PRIETO-GARCIA, J.; HEINRICH, M. Resins and gums in historical iatrosophia texts from Cyprus - a botanical and medico-pharmacological approach. Front. Pharmacol., v.2, p.1-26, 2011.

NAZNEEN, B.; WESELY, E.G.; JOHNSON, M. FT-IR studies on the leaves of Albizia lebbeck benth. Int. J. Pharm. Pharm. Sci., v.4, p.293-296, 2012.

NEP, E.I.; CONWAY, B.R. Characterization of grewia gum, a potential pharmaceutical excipient. J. Excipients Food Chem., v.1, p.30-40, 2010.

ODEKU, O.A. Assessment of Albizia zygia gum as a binding agent in tablet formulations. Acta Pharm., v.55, p.263-276, 2005.

REZA, E.; MOHAMMAD, A.; YOUSEF, F. Assessment of Ferula gummosa gum as a binding agent in tablet formulations. Acta. Pol. Pharm., v.69, p.291-298, 2012.

SAROJINI, S.; DEEPTHI, S.; KUNAM, M.R.; JAYANTHI, B. Effect of natural almond gum as a binder in the formulation of diclofenac sodium tablets. IPPSR. abbreviation, v.1, p.55-60, 2010. 
SATYAM, G.; SHIVANI, S.; GARIMA, G.; NITIN, S.; SHARMA, P.K. Isolation and evaluation of binding property of pappaya starch in diclofenac sodium tablet. Int. J. Pharm. Tech. Res., v.2, p.1508-1512, 2010.

SHINGALA, V.K.; SINGH,A.K.; YADAV, S.K.; SIVAKUMAR, T. Design and characterization of Diclofenac sodium tablets containing Mangifera indica resin as release retardant, Int. J. Pharm. Tech. Res., v.2, p.2107-2111, 2010.

SHIVANAND, P. Instamodel in the development and evaluation of Diclofenac sodium matrix tablet and its effects of release of drug from matrix dosage forms. Int. J. Pham. Life Sci., v.1, p.241-245, 2010.
SINHA, V.R.; KUMARIA, R. Binders for colon specific drug delivery: an in vitro evaluation. Int. J. Pharm., v.249, p.23$31,2002$.

SIVA, P.G.; MOHINI, K. Formulation and evaluation of sustained release tablets of Carvedilol. Int. Res. J. Pharm. Appl. Sci., v.2, p.78-83, 2012.

United States Pharmacopoeia. United States Pharmacopoeial Convention, USP 27. Asian Edition. Inc. at Washington D.C, 2007. p.1795.

Received for publication on $13^{\text {th }}$ November 2012 Accepted for publication on 12 November 2013 